\title{
Overweight and obesity in school children aged 5 to 11 years participating in food assistance programs in Mexico
}

\author{
Lucía Cuevas-Nasu, MSc,, (I) Bernardo Hernández-Prado, PhD, (1) Teresa Shamah-Levy, MSc, (1) \\ Eric A Monterrubio, MSc, (1) María del Carmen Morales-Ruan, MSc, ${ }^{(1)}$ Lidia B Moreno-Macías, BSc, ${ }^{(2)}$
}

\section{Cuevas-Nasu L, Hernández-Prado B, Shamah-Levy T, Monterrubio EA, Morales-Ruan MC, Moreno-Macías LB. Overweight and obesity in school children aged 5 to II years participating in food assistance programs in Mexico. Salud Publica Mex 2009;5I suppl 4:S630-S637.}

\begin{abstract}
Objective. To determine the association between overweight and obesity among Mexican school-aged children and participation in the Liconsa milk and the School Breakfast food assistance programs. Material and Methods. Data from 15003 school-aged children included in the Mexican National Health and Nutrition Survey 2006 (ENSANUT 2006) were analyzed. Information on body mass index (BMI) and participation in food assistance programs was obtained. Descriptive analyses were conducted and logistic regression models were adjusted. Results. Prevalence of overweight and obesity was $17.3 \%$ and $9 \%$, respectively. No significant association between overweight and obesity and participation in Liconsa was found.Among school-aged children in the middle socioeconomic status quintile, those enrolled in the School Breakfast program were more likely to be overweight than those not enrolled $(O R=1.6,95 \% \mathrm{Cl}$ I.I, 2.3). Conclusions. We found no association between the Liconsa and the School Breakfast programs and overweight or obesity in school-aged children.
\end{abstract}

Key words: obesity; children; government programs; Mexico
Cuevas-Nasu L, Hernández-Prado B, Shamah-Levy T, Monterrubio EA, Morales-Ruan MC, Moreno-Macías LB. Sobrepeso y obesidad en niños de 5 a II años de edad beneficiarios de programas de ayuda alimentaria en México Salud Publica Mex 2009;5 I supl 4:S630-S637.

\section{Resumen}

Objetivo. Determinar la asociación entre el sobrepeso y la obesidad en niños de edad escolar y la pertenencia a los programas de asistencia alimentaria Liconsa o Desayunos Escolares en México. Material y métodos. Se analizó la información de 15003 niños en edad escolar de la Encuesta Nacional de Salud y Nutrición 2006 (ENSANUT 2006). Se obtuvo el índice de masa corporal (IMC) e información sobre participación en programas de asistencia alimentaria. Se realizaron análisis descriptivos y se ajustaron modelos de regresión logística. Resultados. La prevalencia de sobrepeso y obesidad fue de 17.3 y $9 \%$, respectivamente. No hubo asociación significativa entre el sobrepeso y obesidad y ser beneficiario de Liconsa. En el quintil socioeconómico medio, los beneficiarios de Desayunos Escolares tuvieron mayores posibilidades de presentar sobrepeso que los no beneficiarios $(R M=I .6, I C 95 \%$ I.I, 2.3$)$. Conclusiones. No se encontró asociación entre ser beneficiario de Liconsa o Desayunos Escolares con el sobrepeso y obesidad en este grupo de edad.

Palabras clave: obesidad; escolares; programas de gobierno; México

(I) Instituto Nacional de Salud Pública. Cuernavaca, Morelos, México.

(2) Facultad de Medicina. Universidad Autónoma de Yucatán. Yucatán, México.

Received on: April II, 2008 • Accepted on: March 31, 2009

Address reprint requests to: MSc. Lucía Cuevas Nasu. Centro de Investigaciones en Nutrición y Salud. Instituto Nacional de Salud Pública. Av. Universidad 655, col. Santa María Ahuacatitlán. 62100 Cuernavaca, Morelos, México.

E-mail: Icuevas@insp.mx 
$\mathrm{M}$ exico has a long history of implementing food assistance programs. The objective of these programs has been to enhance the nutritional status of vulnerable populations and to improve family living conditions. Currently, the most widely implemented national food assistance programs focusing on school-aged children (children aged 5 to 11 years) are the Liconsa milk program and the School Breakfast program.

The goal of the School Breakfast program, directed by the National System for the Integral Family Development (DIF), is to improve the nutritional status of preschool and school-aged children, thereby enabling children's preparedness for learning and decreasing school dropout. More than 5.6 million breakfasts are distributed daily to preschool, elementary and special education students who are identified as at-risk for undernutrition and who attend schools regulated by the Secretariat of Public Education (SEP). Breakfast provides roughly $30 \%$ of the recommended daily energy and protein dietary intake. ${ }^{1}$

Liconsa is a social assistance program which aims to enhance the nutritional status of low-income families by providing non-skimmed milk fortified with vitamins and minerals for children aged 6 months to 15 years, pregnant and breast-feeding women, women 45 to 59 years old, people with chronic diseases, handicapped persons older than 12 years and adults older than 60 years. Currently, the program benefits 5820762 individuals and distributes roughly 3142000 liters of milk to 1800 municipalities daily. Milk supply for each beneficiary household varies from 4 to 24 liters per week. ${ }^{2}$ The Liconsa milk program is assessed according to government guidelines; evaluation includes coverage, impact, cost-benefit analysis and recipient's perception. The evaluation of the program has documented an improvement in nutritional status and children's development and decreased anemia within the recipient population. ${ }^{3}$

According to data from the Mexican National Health and Nutrition Survey 2006 (ENSANUT 2006), the combined prevalence of overweight and obesity among the school-aged children population group in Mexico increased from $18.6 \%$ to $26 \%$ in the past 7 years. ${ }^{4}$ Originally, food assistance programs were created in order to deal with nutritional deficiencies, especially undernutrition; ${ }^{5}$ nevertheless, because the prevalence of overweight and obesity has increased in the last decades in the school-age population in Mexico, the programs face a different nutritional profile than the one that existed when they were created. Since the composition of the food provided by this program may have a substantial caloric content, and these programs may target not only the poorest populations in Mexico, it is worthwhile to question if the programs may be contributing to overweight and obesity problems, rather than solving the undernutrition problems of the population.

To date, the association between overweight and obesity in children and participation in any food assistance program has not been studied.

This study aims to determine the association between the prevalence of overweight and obesity among Mexican school-aged children with enrollment in School Breakfasts and Liconsa milk food assistance programs.

\section{Material and Methods}

\section{Population and sample size}

Data from the school-aged Mexican population 5 to 11 years old included in the ENSANUT 2006 conducted from October 2005 to May 2006 were analyzed. The survey collected information from a probabilistic sample representative at the national and state levels of four regions across the country. This sample included rural and urban localities. The ENSANUT 2006 was designed as a probabilistic, multistage, stratified and clustered study. Sample size calculation and methodology have been described elsewhere. ${ }^{6}$

Before data collection, written consent from children's parents or guardians was obtained. Survey protocol was approved by the Ethics, Research, and Biosecurity Institutional Review Boards from the National Institute of Public Health (INSP).

\section{Study design}

A cross-sectional study was carried out to evaluate the prevalence of overweight and obesity in school children aged 5 to 11 years and any association with participation in the Liconsa or the School Breakfast food assistance programs. Nutritional status was assessed by calculating body mass index $\left[\mathrm{BMI}=\right.$ weight $(\mathrm{kg}) /$ height $\left.\left(\mathrm{m}^{2}\right)\right]$. This index was used to classify children with overweight or obesity according to the specific cutoff points for age and sex recommended by the International Obesity Task Force. ${ }^{7}$ These cutoff points are based on an international reference population that includes data from several countries and generates specific BMI centiles for children related to BMI cutoff points for adults $\left(25 \mathrm{~kg} / \mathrm{m}^{2}\right.$ for overweight and $30 \mathrm{~kg} / \mathrm{m}^{2}$ for obesity). BMI values below 10 and above 38 were excluded as implausible.

A questionnaire on food assistance programs was administered to mothers of children selected for the study at their homes. Specific questions were asked about the milk assistance program Liconsa, and a copy of the mother's affiliation card was requested to verify the names of the beneficiaries. 
Independent variables included participation in the Liconsa or the School Breakfast programs and variables that may potentially confound the association between overweight/obesity and the participation in those programs, such as region of residence (north, center, Mexico City, and south), living in urban or rural localities (population over or under 2500 inhabitants, respectively), sex, age, height-for-age z-score, socioeconomic status index (made up by principal component analysis with variables such as flooring, potable water, ownership of electronic appliances such as radio, television, refrigerator, washing machine, and stove) according to the indices established by the 1999 National Nutrition Survey (ENN 99), ${ }^{8}$ and enrollment in other social assistance programs, including Oportunidades, Despensas del Programa de Apoyo Alimentario -PAL(food supplies), Cocinas del DIF (DIF Kitchens), Dietary Supplement (vitamins and minerals) and support from non-governmental organizations.

\section{Data collection and analysis}

Anthropometric data was obtained using the weight and height measurement techniques recommended in the INSP Nutrition Project Procedure Handbook. ${ }^{9}$ Personnel was trained to follow these standardized recommended procedures and protocols. ${ }^{10,11}$ Weight was measured with electronic scales accurate to $100 \mathrm{~g}$ (Tanita Corporation, model 1631, China), and height with 1-mm-unit 2-m stadimeters (Dynatop, model E-1, Mexico).

Experts developed the questionnaire for the survey and trained the interviewers. INSP personnel developed an electronic questionnaire using the Microsoft Visual Fox Pro 7.0 development program. During the interview, interviewers equipped with laptop computers were able to enter data directly into the electronic questionnaires. All data were backed-up and sent daily to the INSP. The database was cleaned and missing or implausible weight and height values were revised and corrected.

\section{Analysis}

All statistic analyses were adjusted for the complex survey design. ${ }^{12}$ A descriptive data analysis was carried out to characterize the study population. Multinomial logistic regression models (using three levels: without overweight or obesity, overweight, and obesity) were adjusted for biological plausiblity and socially relevant variables to evaluate the association between prevalence of overweight and obesity and participation in each of the assessed programs. Crude and adjusted odds ratios (OR) with $95 \%$ confidence intervals were estimated to identify the association between participation in the Liconsa and the School Breakfast programs and the likelihood of be- ing overweight or obese. Non-beneficiary children in the same age group living in urban localities were used as a reference population for the Liconsa milk program. For the School Breakfast program, the reference population included non-beneficiary children in the same age group living in either urban or rural localities. We explored some interactions with biological and social relevance, specifically between participation in food assistance programs with residence region and socioeconomic status. The interactions were considered statistically significant when $p$ $<0.1^{13}$ and principal effects were considered significant if they had a $p<0.05$. Statistical analyses took into account the stratified design and the clustered sampling. The expansion factor was included to consider the sample distribution at the national level. Data analysis was performed using the StataSVY module for complex samples (StataCorp., Stata Statistical Software: Release 7.0. College Station, TX: Stata Corporation, 2001) and SPSS (SPSS for Windows, Rel. 15.0. 2006. Chicago: SPSS Inc.).

\section{Results}

Prevalence of overweight and obesity was estimated in 15003 children, representing 15714000 school-aged children nationwide, considering the expansion factor. Distribution according to participation in a food assistance program indicated that at the national level 8.8\% of school children were recipients of the Liconsa milk program, while $13.4 \%$ of school children were enrolled in the School Breakfast program. Only 2\% of children were beneficiaries of both programs. Prevalence of overweight and obesity was $21.4 \%$ in school-aged children beneficiaries of any food assistance program (data not shown). Table I shows the descriptive characteristics of the study population according to different programs studied.

In Mexico, $17.3 \%$ of school-aged children were overweight and $9.0 \%$ were obese. The highest prevalence of overweight (19.1\%) and obesity (13.4\%) corresponded to those children who benefit from the Liconsa milk program, of whom $95.2 \%$ live in urban localities. About $55 \%$ of these children were in the highest socioeconomic status quintiles and nearly $63 \%$ lived in the center region of the country (Table I).

Children receiving the School Breakfast program showed a lower prevalence of overweight (17.8\%) and obesity $(8.0 \%)$ compared to those receiving the Liconsa milk program. Slightly more than $50 \%$ of DIF beneficiaries lived in urban localities, were in the socioeconomic status lowest quintiles (1 and 2), and were mainly distributed in the center and south regions of the country (Table I). Mean age was 8.1 years $(95 \% \mathrm{CI}$, 8.0-8.1) (Table II).

Logistic regression models were fit to evaluate the association of overweight and obesity and participation 
Table I

Characteristics of the 5- to I I-Years-old population from ENSANUT 2006, ACCORDING TO THE FOOD ASSISTANCE PROGRAM IN WHICH THEY ARE ENROLLED

\begin{tabular}{|c|c|c|c|c|}
\hline & $\begin{array}{l}\text { National } \\
(n=15003)\end{array}$ & $\begin{array}{l}\text { Without program } \\
\qquad(n=8 \quad 0 / 2)\end{array}$ & $\begin{array}{l}\text { Liconsa milk } \\
\qquad(n=8 / 5)\end{array}$ & $\begin{array}{c}\text { School Breakfasts } \\
\quad(n=2084)\end{array}$ \\
\hline Variables & $\%(95 \% \mathrm{Cl})^{*}$ & $\%(95 \% \mathrm{Cl})^{*}$ & $\%(95 \% \mathrm{Cl})^{*}$ & $\%(95 \% \mathrm{Cl})^{*}$ \\
\hline
\end{tabular}

Sex

\begin{tabular}{lllllllllll} 
Male & 7507 & $49.8(48.5,51.0)$ & 4015 & $49.6(48.0,51.2)$ & 419 & $55.4(49.7,61.0)$ & I 045 & $51.1(47.8,54.4)$ \\
\hline
\end{tabular}

$\begin{array}{llllllllll}\text { Female } & 7496 & 50.2(49.0,51.5) & 3997 & 50.4(48.8,52.0) & 396 & 44.6(39.0,50.3) & \text { I } 039 & 48.9(45.6,52.2)\end{array}$

Nutritional status

\begin{tabular}{|c|c|c|c|c|c|c|c|c|}
\hline Without overweight or obesity & 10916 & $73.8(72.4,75.1)$ & 5420 & $70.0(68.5,71.6)$ & 561 & $67.5(60.5,73.7)$ & 1606 & $74.2(70.4,77.8)$ \\
\hline Overweight & 2653 & I7.3 (I6.2, I8.3) & 1611 & $19.3(\mid 8.0,20.7)$ & $16 \mid$ & I9.I (14.5,24.8) & 338 & $17.8(|4.7,2| .3)$ \\
\hline Obesity & I 434 & $9.0(8.2,9.8)$ & 981 & $10.6(9.7, \mid \mathrm{I} .6)$ & 93 & I $3.4(8.7,20.2)$ & 140 & $8.0(5.9,10.8)$ \\
\hline
\end{tabular}

Region

\begin{tabular}{lrcrrrrrr} 
North & 3296 & $18.7(16.5,21.2)$ & 2480 & $26.4(23.2,30.0)$ & 80 & $4.3(2.9,6.3)$ & 320 & $14.0(10.2,18.8)$ \\
\hline Center & 5768 & $40.6(36.8,44.5)$ & 2873 & $40.9(36.5,45.5)$ & 407 & $62.6(52.3,71.9)$ & 803 & $33.7(27.5,40.5)$ \\
\hline Mexico City & 309 & $6.4(4.5,8.8)$ & 135 & $4.4(3.1,6.3)$ & 85 & $21.4(13.8,31.6)$ & 107 & $16.4(I I .2,23.3)$ \\
\hline South & 5630 & $34.3(31.1,37.7)$ & 2524 & $28.2(24.7,32.0)$ & 243 & $11.7(8.6,15.7)$ & 854 & $36.0(30.0,42.4)$
\end{tabular}

Residence locality

\begin{tabular}{|c|c|c|c|c|c|c|c|c|}
\hline Urban & 10081 & $72.0(69.7,74.1)$ & 7099 & $89.1(86.8,91.0)$ & 716 & $95.2(92.3,97.0)$ & 959 & $55.9(49.8,61.9)$ \\
\hline & 4922 & $28.0(25.9,30.3)$ & 913 & $10.9(9.0,13.2)$ & 99 & $4.8(3.0,7.7)$ & 1125 & $44.0(38.0,50.2)$ \\
\hline
\end{tabular}

Socioeconomic status

\begin{tabular}{|c|c|c|c|c|c|c|c|c|}
\hline Quintile I & 2928 & $20.1(18.2,22.1)$ & 635 & $8.9(7.4,10.6)$ & 58 & $6.0(3.4,10.1)$ & 576 & $27.1(22.6,32.1)$ \\
\hline Quintile 2 & 3341 & $20.2(18.9,21.7)$ & 1397 & $16.5(14.8,18.4)$ & 165 & I8.I $(14.0,23.0)$ & 613 & $25.1(22.1,28.3)$ \\
\hline Quintile 3 & 3250 & $19.6(18.4,20.9)$ & 1799 & $21.1(19.5,22.8)$ & 224 & $21,2(16.4,27.0)$ & 451 & $20.2(17.3,23.5)$ \\
\hline Quintile 4 & 2930 & $20.3(19.0,21.6)$ & 2070 & $25.4(23.6,27.4)$ & 204 & $27.7(22.8,33.2)$ & 299 & I8.8 (I5.4,22.7) \\
\hline Quintile 5 & 2498 & $19.7(18.0,21.6)$ & 2070 & $28 . I(25.6,30.7)$ & 164 & $27 . I(21.0,34.2)$ & 139 & $8.9(6.6,|1| .7)$ \\
\hline
\end{tabular}

* Prevalences and confidence intervals were obtained considering the sampling design of the ENSANUT 2006

₹ Total population included children with other social programs (Oportunidades, Programa de Apoyo Alimentario -PAL- food supplies, non-governmental organizations, vitamin and mineral supplement and other local programs)

Table II

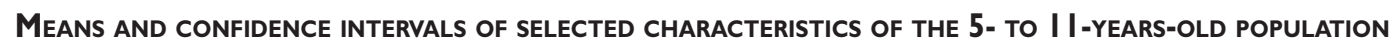
FROM ENSANUT 2006, ACCORDING TO THE FOOD ASSISTANCE PROGRAM IN WHICH THEY ARE ENROLLED

\begin{tabular}{|c|c|c|c|c|}
\hline Variables & $\begin{array}{c}\text { National } \\
(n=15003) \\
\text { Means }(95 \% \mathrm{Cl})^{*}\end{array}$ & $\begin{array}{l}\text { Without program } \\
\quad(n=80 \mathrm{O} 2) \\
\text { Means }(95 \% \mathrm{Cl})^{*}\end{array}$ & $\begin{array}{c}\text { Liconsa milk } \\
\quad(n=8 / 5) \\
\text { Means }(95 \% \mathrm{Cl})^{*}\end{array}$ & $\begin{array}{l}\text { School Breakfasts } \\
\quad(n=2084) \\
\text { Means }(95 \% \mathrm{Cl})^{*}\end{array}$ \\
\hline Age (years) & $8.1(8.0,8.1)$ & $8.1(8.0,8.2)$ & $8.1(7.8,8.3)$ & $7.8(7.6,7.9)$ \\
\hline Weight (kg) & $29.8(29.5,30.1)$ & $30.8(30.4,3 \mid .2)$ & $30.9(29.6,32.3)$ & $28.2(27.4,29.0)$ \\
\hline Height $(\mathrm{cm})$ & I27.I $(126.7,127.6)$ & I28.2 (I27.7, I28.8) & I28.3 $(126.6,130.0)$ & $124.6(123.5,125.6)$ \\
\hline BMI & $17.9(17.8,18.0)$ & I8.I $(|8.0| 8.3)$, & $18.2(17.7,18.7)$ & I7.7 (I7.4, I7.9) \\
\hline Height-for-age z-score & $-0.5 \mathrm{I}(-0.55,-0.46)$ & $-0.32(-0.38,-0.27)$ & $-0.28(-0.39,-0.17)$ & $-0.66(-0.76,-0.55)$ \\
\hline
\end{tabular}

* Means and confidence intervals were obtained considering the sampling design of the ENSANUT 2006 
in the Liconsa and the School Breakfast programs. Adjustment was made for the following covariables: region, residence locality, sex, socioeconomic status, age, and height-for-age z-score. Comparison groups for these models were children of the same age group, non-beneficiaries of the programs and, regarding the Liconsa milk program, living in urban localities.

The logistic models found no association between overweight and participation in the Liconsa milk program $(\mathrm{OR}=0.9,95 \% \mathrm{CI}$ 0.7-1.4, after adjustment for the above-mentioned covariates). An association between obesity and being enrolled in the Liconsa milk program was found for the crude model $(\mathrm{OR}=$ 1.7, 95\% CI 1.0-2.9). However, the magnitude of the association decreased and was not significantly different from the null value after adjustment for the covariables ( $\mathrm{OR}=1.4,95 \%$ CI 0.8-2.3) (Table III). No significant interactions were found between region and

Table III

Odds RATIOS OF BEING OVERWEIGHT AND OBESE* IN SCHOOL CHILDREN (5 TO I I YEARS OLD) BENEFICIARIES OF SOCIAL programs. Mexico, ENSANUT 2006

Characteristics $\quad \begin{gathered}\text { None } \\ \text { adjusted }\end{gathered}$

$O R$

$(95 \%$ Cl)

Model (I) without interaction

Model (2) with interaction $\begin{array}{cccc}\text { Adjusted } & (95 \% \mathrm{Cl}) & & \text { Adjusted } \\ \text { OR } & \text { OR } & & \end{array}$

$(95 \% \mathrm{Cl})$

Overweight status outcome

Enrolled in the School Breakfast program

$(0.8, I .3)$

1.2

$(0.99,1.5)$

Socioeconomic status quintiles (SSQ)

\begin{tabular}{|c|c|c|c|c|c|c|}
\hline SSQ I (reference) & I & - & 1 & - & --- & --- \\
\hline SSQ 2 & 1.5 & $(1.2,1.9)$ & 1.1 & $(0.8, I .4)$ & -..- & --- \\
\hline SSQ 3 & 1.9 & $(1.4,2.4)$ & 1.2 & $(0.9,1.6)$ & $-\ldots$ & --- \\
\hline SSQ 4 & 2.3 & $(1.8,2.9)$ & 1.3 & $(0.9,1.7)$ & --- & --- \\
\hline SSQ 5 & 2.7 & $(2.1,3.6)$ & 1.5 & $(1.0,2.1)$ & --- & --- \\
\hline
\end{tabular}

Interaction School Breakfast program $\times$ SSQ

School Breakfast program in the SSQ

School Breakfast program in the SSQ 2

School Breakfast program in the SSQ 3

School Breakfast program in the SSQ 4

School Breakfast program in the SSQ 5

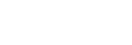

Enrolled in the Liconsa milk program

Enrolled in other programs ${ }^{\S}$

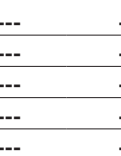

---
---
---

\begin{tabular}{cccc}
-- & -- & 1 & -- \\
\hline-- & --- & 0.9 & $(0.6,1.2)$ \\
--- & -- & 1.6 & $(1.1,2.3)$ \\
-- & --- & 1.4 & $(0.9,2.5)$ \\
--- & --- & 0.9 & $(0.4,2.1)$
\end{tabular}

besity status outcome

Enrolled in the School Breakfast program

1.2

$(0.9, I .7)$

0.9

$(0.7,1.4)$

0.9

$(0.7,1.4)$

0.5

$(0.4,0.6)$

0.7

$(0.6,0.8)$

0.7

$(0.6,0.8)$

cioeconomic status quintiles (SSQ)

SSQ I (reference)

\begin{tabular}{ll} 
SSQ 2 & 2.9 \\
\hline SSQ 3 & 3.7 \\
\hline SSQ 4 & 5.1 \\
\hline SSQ 5 & 5.0
\end{tabular}

0.9

$(0.6,1.2)$

1.2

$(0.8,1.6)$

\begin{tabular}{llllll}
1 & - & 1 & - & --- & --- \\
\hline 2.9 & $(2.0,4.2)$ & 1.7 & $(1.2,2.5)$ & --- & --- \\
\hline 3.7 & $(2.6,5.2)$ & 1.7 & $(1.2,2.5)$ & --- & --- \\
\hline 5.1 & $(3.6,7.2)$ & 2.0 & $(1.4,2.9)$ & --- & --- \\
\hline 5.0 & $(3.5,7.2)$ & 1.9 & $(1.2,2.8)$ & --- & ---
\end{tabular}

Interaction School Breakfast program $x$ SSQ

School Breakfast program in the SSQ I

School Breakfast program in the SSQ 2

School Breakfast program in the SSQ 3

School Breakfast program in the SSQ 4

School Breakfast program in the SSQ 5

$\begin{array}{cccccc} & & & & & \\ --- & --- & -- & \text { I } & -- \\ --- & -- & -- & -- & 0.8 & (0.4,1.6) \\ --- & -- & -- & -- & 1.4 & (0.8,2.3) \\ --- & -- & -- & -- & 1.7 & (0.8,3.5) \\ --- & --- & -- & -- & 1.1 & (0.4,3.0) \\ 1.7 & (1.0,2.9) & 1.4 & (0.8,2.3) & 1.4 & (0.8,2.3) \\ 0.3 & (0.3,0.4) & 0.7 & (0.6,0.9) & 0.7 & (0.6,0.9)\end{array}$

Enrolled in the Liconsa milk program

Enrolled in other programs ${ }^{\S}$

$(0.3,0.4)$

0.7

$(0.6,0.9)$

0.7

$(0.6,0.9)$

* International Obesity Task Force (IOTF) overweight and obesity classification criteria were used

$\ddagger$ Reference category for the OR estimation was non-beneficiary of the program

$\S$ Reference category for the OR estimation was non-enrolled in other programs

\# Adjusted for socioeconomic status; with and without interaction among socioeconomic status and enrolled in the School Breakfast program, participation in the Liconsa milk program, participation in other programs, regions, living in urban or rural localities, sex, age, and z-score for height/age 
socioeconomic status and participation in the Liconsa milk program.

For the School Breakfast program, a marginal association with the likelihood of being overweight in children who benefit from the program was found $(\mathrm{OR}=1.295 \% \mathrm{CI} 0.99,1.5)$ after adjustment for region, residence locality, sex, socioeconomic status, and heightfor-age z-score covariables (Table III). The magnitude of the relationship between the School Breakfast program and prevalence of obesity or overweight varied according to socioeconomic stratum. Children from the middle socioeconomic status quintile (quintile 3 ) who received the program were more likely to be overweight than those who did not receive the program $(\mathrm{OR}=1.6,95 \%$ CI 1.1, 2.3) (Table III).

No association was found between obesity $(\mathrm{OR}=$ 1.2, 95\% CI 0.8-1.6) and participation in the School Breakfast program after adjustment for the variables mentioned above (Table III).

It was not possible to explore the interaction between participation in the Liconsa milk program and in the School Breakfast program, as only 2\% of the schoolaged children are beneficiaries of both programs.

\section{Discussion}

Results from this study showed no positive association between overweight and obesity in school-aged children and participation in the Liconsa milk program when compared to non-recipient, urban school-aged children. In addition, no positive association was found for obesity for children participating in the School Breakfast program when compared with school-aged, non-recipient children, after adjustment for potentially confounding factors. However, we did observe a trend for being overweight in children who are beneficiaries of this program with respect to socioeconomic status. Within the middle socioeconomic status quintile (quintile 3), children who received the School Breakfast program were more likely to be overweight than those who did not receive it.

Food assistance programs in Mexico have historically focused on mitigating nutritional deficiencies in vulnerable population groups, specifically infants. ${ }^{5}$ In this study, we found that a fifth of the school-aged children $(21.4 \%)$ who benefit from any food assistance program have an excess of weight, up from 19.5\% in 1999. ${ }^{14}$ These programs need to be redirected to target the existing nutritional problems of the Mexican population. ${ }^{15}$ We must ensure that food assistance programs are not contributing to the development of overweight and obesity in the beneficiary population.
A state-level study of the School Breakfast program had similar results to our national-level study. Neither found a positive association between the program and increased prevalence of obesity and overweight. ${ }^{16}$ The findings from these studies are consistent with those from studies conducted in the United States, which have not found an increase in the likelihood of being overweight due to participation in any food assistance program for this age group. ${ }^{17-19}$ Nonetheless, the higher likelihood of being overweight for those who receive the program found in the middle socioeconomic status quintile might be related to a greater availability among this socioeconomic strata of processed food items, such as refined flour and sugars with high quantities of energy.

An evaluation carried out in participants from the School Breakfast program in the State of Mexico showed that one of the most consumed food items according to the analysis of food frequency semiquantitative questionnaires is soda. Additionally, this same evaluation found that the main food items that $38 \%$ of the children enrolled in the program consume after leaving school are sandwiches, hamburgers, hot dogs, tortas and tamales, potentially worsening the overweight and obesity trends. ${ }^{20}$

An important implication of this study is that, given the current nutritional status of the Mexican population, food assistance programs may not be suitably targeting populations to meet their stated objectives. We found that more than $95 \%$ of school children enrolled in the Liconsa milk program live in urban localities in the center region of the country and more than two thirds are in the highest socioeconomic status quintiles (4 and 5). Thus, the current recipient population does not meet program guidelines, ${ }^{2}$ which state that milk subsidies should target poor and marginal population groups. We suggest a more detailed analysis of the current beneficiary population and a redistribution of benefits to the poorest families with school-aged children.

Milk distributed through the Liconsa milk program was supplemented with micronutrients in 2004. In subsequent evaluations, it was noted that among children under 5 years old, there was a noticeable decrease in anemia prevalence and iron deficiency in children who started drinking supplemented milk from an early age, ${ }^{3}$ higher stature, more muscle mass, and better mental development. ${ }^{2}$ Among school-aged children there is a high prevalence of iron deficiency anemia $(17 \%)_{i}^{21}$ however, we still lack sufficient evidence for school-aged children as to the effect of Liconsa milk consumption on decreasing such iron deficiency and increasing the body composition of the beneficiaries. Given the high prevalence of overweight and obesity, we recommend 
evaluating whether the consumption of whole enriched milk is recommended for this age group. ${ }^{22}$

With respect to the School Breakfast program, slightly more than half of the beneficiaries live in urban localities and more than $50 \%$ of the children are in the lowest socioeconomic status quintiles (1 and 2). According to the program guidelines, the target population should be children at risk of malnutrition or with some degree of current malnutrition. ${ }^{1}$ In this study, a quarter of the recipient children were found to have an excess of weight (BMI > 25) similar to the current national prevalence of excessive weight in the schoolaged population $(26 \%) .{ }^{4}$ Even though overweight and obesity among recipient children may be associated with a broader process of increasing overweight and obesity rates independent of participation in this program, it is advisable to redefine program objectives to help decrease this major health problem among schoolaged children.

This study has some limitations that may affect the interpretation of the results. Because of its crosssectional design, it is not possible to establish causality. Nevertheless, the probabilistic national sample allowed us to observe the distribution of this phenomenon at the national level, allowing for association inference. Another limitation is that benefit consumption (i.e. milk or school breakfast intake) and other variables such as diet and physical activity, which may be influential for the development of excess weight, were not controlled for in the study because they were not available for the whole sample of school-aged children included in this analysis.

In Mexico, there is still a lack of information about the association between overweight and obesity in school-aged children and enrollment in any food assistance program. This study begins to fill the gap of information on this issue but other studies are needed to fully assess this issue. This study found no evidence of a specific association between the Liconsa milk assistance program and the DIF School Breakfast program with overweight or obesity among school-aged children in Mexico. However, we did observe a high prevalence of overweight and obesity in food assistance beneficiaries from this age group. Therefore, we recommend that each program be evaluated according to its stated objectives and assure that the benefits of these programs are being directed appropriately to targeted, nutritionally vulnerable populations. Additionally, these programs should also assess and formulate objectives that will help address the growing epidemic of overweight and obesity among Mexican school-aged children population.

\section{References}

I. Sistema Nacional para el Desarrollo Integral de la Familia DIF. Programa de Desayunos Escolares, lineamientos generales de operación (2007). Mexico: DIF, June 6, 2007. [Consulted 2007 June 6]. Available at: http:// www.dif.gob.mx/54.html\#desayunos.

2. Secretaría de Desarrollo Social. Programa de abasto social de leche Liconsa, lineamientos generales de operación (2007). Mexico: LICONSA, 2007. [Consulted 2007 June 7]. Available at: http://www.liconsa.gob.mx/ 3. Villalpando S, Shamah T, Rivera JA, Lara Y, Monterrubio E. Fortifying milk with ferrous gluconate and zinc oxide in a public nutrition program reduced the prevalence of anemia in toddlers. J Nutr 2006; 136:2633-2637. 4. Rivera-Dommarco J, Cuevas-Nasu L, Shamah-Levy T,VillalpandoHernández S, Ávila-Arcos MA, Jimenez-Aguilar A. Estado nutricio. In: Olaiz-Fernández G, Rivera-Dommarco J, Shamah-Levy T, Rojas R, Villalpando-Hernández S, Hernández-Avila M, et al. Encuesta Nacional de Salud y Nutrición 2006. Cuernavaca, México: Instituto Nacional de Salud Pública, 2006: 85-103.

5. Barquera S, Rivera-Dommarco JA, Gasca-García A. Políticas y programas de alimentación y nutrición en México. Salud Publica Mex 200 I;43:I-I4. 6. Palma O, Shamah-Levy T, Franco A, Olaiz G, Méndez-Ramírez I. Metodología. In: Olaiz-Fernández G, Rivera-Dommarco J, Shamah-Levy T, Rojas R,Villalpando-Hernández S, Hernández-Avila M, et al. Encuesta Nacional de Salud y Nutrición 2006. Cuernavaca, México: Instituto Nacional de Salud Pública, 2006: 19-33.

7. Cole TJ, Bellizzi MC, Flegal KM, Dietz WH. Establishing a standard definition for child overweight and obesity worldwide: International survey. BMJ 2000;320: 1240-1243.

8. Resano E, Mendez I, Shamah T, Rivera J, Sepulveda J. Methods of the National Nutrition Survey 1999. Salud Publica Mex 2003:45 Suppl 4:558-564.

9. Cuevas-Nasu L, García-Feregrino R, Mendoza-Olivares JS, JaimesTerán MS, Shamah-Levy T, Rivera-Dommarco J.Antropometría. In: Manual de procedimientos para proyectos de nutrición. Cuernavaca, Mexico: Instituto Nacional de Salud Pública, 2006.Available at: http://.www.insp.mx. I0. Lohman TG, Roche AF, Martorell R, ed.Anthropometrics standardization reference manual. Champaign (IL): Human Kinetics Books, 1988.

I I. Habicht JP. Estandarización de métodos epidemiológicos cuantitativos sobre el terreno. Bol Oficina Sanit Panam 1974;76:375-385.

12. Skinner CJ, Holt D, Smith TMF. Applied Analysis of Complex Surveys. New York (NY): John Wiley \& Sons, 1989.

13. Hosmer DW, Lemeshow MS. Applied Logistic Regression. New York (NY): John Wiley \& Sons, 1989.

14. Hernandez B, Cuevas-Nasu L, Shamah-Levy T, Monterrubio EA, Ramirez-Silva $\mathrm{Cl}$, Garcia-Feregrino R, et al. Factors associated with overweight and obesity in Mexican school-age children: Results from the National Nutrition Survey 1999. Salud Publica Mex 2003;45 Suppl 4:S55I-S557.

15. Shamah-Levy T, Rivera-Dommarco J, Nogueira-Flores L, JiménezAguilar A, Mundo-Rosas V, Villalpando-Hernández S. Programas de ayuda alimentaria. In: Olaiz-Fernández G, Rivera-Dommarco J, Shamah-Levy T, Rojas R,Villalpando-Hernández S, Hernández-Avila M, et al. Encuesta Nacional de Salud y Nutrición 2006. Cuernavaca, México: Instituto Nacional de Salud Pública, 2006: |2|-|3|.

16. Ramírez-López E, Grijalva-Haro MI,Valencia ME, Ponce JA,Artalejo E. Impacto de un programa de Desayunos escolares en la prevalencia de obesidad y factores de riesgo cardiovascular en niños sonorenses. Salud Publica Mex 2005;47:126-133.

I7. Ploeg MV, Mancino L, Lin BH, Guthrie J. US food assistance programs and trends in children's weight. Int J Pediatr Obes 2007;29:1-9. 
18. Hofferth SL, Curtin S. Poverty, food programs, and childhood obesity. J Policy Anal Manage 2005;24(4):703-726.

19. Jones SJ, Jahns L, Laraia BA, Haughton B. Lower risk of overweight in school-aged food insecure girls who participate in food assistance: Results from the panel study of income dynamics child development supplement. Arch Pediatr Adolesc Med 2003;157(8):780-784.

20. Instituto Nacional de Salud Pública. Informe final del proyecto "Contribución del programa de desayunos escolares del DIF Estado de México en el estado de nutrición de los niños escolares." Mexico: Instituto Nacional de Salud Pública, 2007.
2I. Villalpando-Hernández S, Mundo-Rosas V, Shamah-Levy T, RiveraDommarco J, Mauricio-López ER.Anemia. In: Olaiz-Fernández G,

Rivera-Dommarco J, Shamah-Levy T, Rojas R, Villalpando-Hernández S, Hernández-Avila M, et al. Encuesta Nacional de Salud y Nutrición 2006. Cuernavaca, México: Instituto Nacional de Salud Pública, 2006: I I I- I 9. 22. US Department of Health and Human Services, US Department of Agriculture, Dietary Advisory Guidelines Committee. Dietary Guidelines for Americans, 2005. [Consulted on 2007 December 7]. Available at: www. healthierus.gov/dietaryguidelines 